\title{
\begin{tabular}{l|cc} 
Media & p-ISSN $1979-3693$ & e-ISSN 2477 - 0647 \\
Stat1Sti1Ka & MEDIA STATISTIKA 12(2) 2019:129-139 \\
http://ejournal.undip.ac.id/index.php/media_statistika
\end{tabular}
}

\section{MODELING CENTRAL JAVA INFLATION AND GRDP RATE USING SPLINE TRUNCATED BIRESPON REGRESSION AND BIRESPON LINEAR MODEL}

\author{
Suparti $^{1}$, Alan Prahutama ${ }^{1}$, Agus Rusgiyono ${ }^{1}$, Sudargo $^{2}$ \\ ${ }^{1}$ Department of Statistics, Faculty of Science and Mathematics, Diponegoro University \\ ${ }^{2}$ PGRI Semarang University \\ e-mail: supartistat@gmail.com
}

DOI: $10.14710 /$ medstat.12.2.129-139

\section{Article Info: \\ Received: 14 October 2019 \\ Accepted: 12 December 2019 \\ Available Online: 30 December 2019}

Keywords:

Inflation, GRDP, Spline Biresponse

\begin{abstract}
Inflation and Gross Regional Domestic Income (GRDP) are two macroeconomic variables of a region that are correlated with each other. GRDP prices constant (real) can be used as an indicator of economic growth in a region from year to year. Inflation is calculated from the CPI rate and economic growth is calculated from the GRDP rate. Inflation and economic growth in an area are influenced by several factors including bank interest rates. Analysis of data consisting of 2 correlated responses can be performed with birespon regression analysis. In this research, modeling of inflation data and the rate of GRDP through birespon data modeling uses spline truncated nonparametric method and birespon linear parametric method. The purpose of this study is to model inflation data and the Central Java GRDP rate using spline truncated birespon regression. The results are compared with the birespon linear regression model. By using quarterly data from the first quarter of 2007 - the second quarter of 2019, the spline truncated model is better than the linear model, because the spline truncated model has a smaller MSE and $\mathrm{R}^{2}$ is greater than the linear model. Both models have the same performance which is quite good.
\end{abstract}

\section{INTRODUCTION}

Inflation is a trend or movement of the general price level that continues over time from one period to the next. The increase in prices of goods is attributable to rising prices of raw materials, lack of goods' availability, lack of infrastructure, or a decrease in the value of currencies against other currencies. This type of inflation is burdensome for producers and consumers because expensive raw materials will lead to higher price of goods, which burdens people's purchasing power. The decreasing purchasing power of the people results in expenditure decrease, and slackening economic growth because the biggest component of growth is contributed by public spending (domestic consumption). 
The increase in price of goods is also attributed by increasing demand. Increasing price for this type of goods is good for producers. It also means that the economy moves faster because of people's purchasing power. The increasing purchasing power of the community will lead to the increase of economic growth.

The link between inflation and economic growth is noteworthy to look at. Excessively low inflation will suppress economic growth and too high inflation will decrease the purchasing power of the people that results in disrupted economy. Therefore, to maintain the inflation rate, we need to pay attention to two factors at the same time, namely the level of inflation that optimizes the economy and at the same time does not reduce people's purchasing power. On the other hand, economic growth is needed to achieve development targets such as job creation, increased national output, tax revenues, poverty alleviation, unemployment reduction and increased levels of community welfare can be achieved. The low rate of economic growth will prevent us from making these targets. Hence, inflation and economic growth are two interrelated subjects. There are several factors to affect inflation and economic growth in a region or a country. According to Agusmianata, et al (2017), the variable interest rate has a significant influence on inflation and according to Fahrika (2016), the interest rate has a positive and significant effect on economic growth in Indonesia. The use of multiple regression modeling demonstrates a relationship between inflation and interest rates on Indonesia's economic growth in the period 2005-2015. Indonesia's economic growth on inflation and interest rates has a strong relationship, while inflation with interest rates has a weak relationship (Indriyani, 2016). Panjaitan and Wardoyo (2016) also conducted a research on the factors that influence inflation in Indonesia. It revealed that the money supply and the BI rate had a significant effect on inflation in Indonesia.

Regression analysis is an analytical method to model two or more data. Regression analysis contains two types of data, namely time series data and cross section data. Time series data is data from a subject that is observed repeatedly over time, while the cross section data is data from several subjects which are only observed once on each subject and are mutually independent. The combined time series and cross section data form longitudinal data (Wu and Zhang, 2006). Longitudinal data contain repeated observations of each subject at different time intervals. This data correlates to the same subject and is independent between different subjects. Regression analysis, be it in time series, cross section or longitudinal data, which involves two correlated response variables used biresponse regression analysis (Fernandes, et al., 2014).

Many researchers have done modeling on time series data with kernel models, local polynomials to model inflation data (Suparti, 2013). They have also done longitudinal data modeling on 7 groups of inflation expenditure using spline, local polynomial and combination of local polynomial-spline truncated together or hybrid (Suparti, et al, 2016, 2018a). However, these previous studies only involved one response.

Some researchs related to biresponse data were conducted by Wulandari and Budiantara (2014), Ampulembang, et al (2017), Pratiwi (2017) and Nurdiani, et al (2018). Wulandari and Budiantara (2014) analyzed the factors that influence the percentage of poor population and per capita food expenditure in East Java using the nonparametric biresponse spline regression. Chamidah and Rifada (2016) estimated the growth media curves of children based on the local linear estimator biresponse. Ampulembang, et al (2016) modeled welfare indicators in Java using the MARS response. Pratiwi (2017) and Nurdiani, et al (2018) modeled spline truncated in biresponse nonparametric regression. 
However, biresponse data modeling conducted by the previous researchers did not apply modeling to economic data such as inflation and economic growth in a region. Because the economic growth of a region can be reflected in the GRDP rate, the current researchers are interested in analyzing biresponse data modeling on inflation data and the Central Java GRDP rate using the spline method and comparing the results with the linear biresponse model. Modeling the data of the response to inflation and the GRDP rate in the study involved one predictor variable of Bank Indonesia interest rates (BI rate).

\section{LITERATURE REVIEW}

\subsection{Spline Univariate}

The general form of the regression model is as follows:

$y_{i}=\beta_{0}+\beta_{1} x_{1 i}+\beta_{2} x_{2 i}+\cdots+\beta_{P} x_{P i}+\varepsilon_{i}$ for $i=1,2, \ldots, n$ and $p=1,2, \ldots, P$ where $\mathrm{n}$ is the number of observations and $\mathrm{m}$ is the number of predictors. The estimation of parameters in the parametric regression equation used Ordinary Least Square (OLS).

This equation can be written as:

$$
y_{i}=\hat{f}\left(x_{i}\right)+\varepsilon_{i}
$$

If $\hat{f}\left(x_{i}\right)$ is an unknown curve, $\hat{f}\left(x_{i}\right)$ is estimated using a nonparametric regression approach. One of the nonparametric regression approaches is to use spline. The function of the truncated spline is as follows:

$$
\begin{aligned}
& \hat{f}\left(x_{i}\right)=\sum_{j=0}^{m-1} \hat{\beta}_{j} x_{i}^{j}+\sum_{j=1}^{r} \hat{\beta}_{j+m-1}\left(x_{i}-k_{j}\right)_{+}^{m-1} \text { the truncated function is as follows: } \\
& \left(x_{i}-k_{j}\right)_{+}^{m-1}=\left\{\begin{array}{c}
\left(x_{i}-k_{j}\right)^{m-1} ; \quad x_{i}-k_{j} \geq 0 \\
0 ; \quad x_{i}-k_{j}<0
\end{array}\right.
\end{aligned}
$$

$\hat{\beta}_{j}$ is a constant that has a real value with $j=0,1, \ldots, m+r-1$ and $\mathrm{k}$ is a knot point. Therefore, the spline regression model is as follows:

$$
y_{i}=\sum_{j=0}^{m-1} \hat{\beta}_{j} x_{i}^{j}+\sum_{j=1}^{r} \hat{\beta}_{j+m-1}\left(x_{i}-k_{j}\right)_{+}^{m-1}+\varepsilon_{i}
$$

\subsection{Optimum Knot Point Selection}

The knot point is the controller value in the spline regression model to get the best model. The optimal knot point is able to produce a spline regression model, in addition to determining the order of the spline. The knots are taken from the distribution of observational data. Some methods to determine the optimal knot point of the spline regression model are Mean Square Error (MSE) and General Cross Validation (GCV). The GCV is formulated as follows:

$$
G C V(k)=\frac{\operatorname{MSE}(k)}{\left(\frac{1}{n} \operatorname{tr}[\mathbf{I}-\mathbf{A}(k)]\right)^{2}}
$$

where 


$$
\operatorname{MSE}(k)=\frac{1}{n} \sum_{i=1}^{n}\left(y_{i}-\hat{y}_{i}\right)^{2}, \text { and } \mathbf{A}(k) \text { resulted from the correlation } \hat{\mathbf{y}}=\mathbf{A}(k) \mathbf{y} .
$$

The smallest MSE or GCV value will give the optimal knot point value

\section{RESEARCH METHODS}

This research examined spline truncated biresponse modeling, and applied it to modeling inflation and GRDP growth rates in Central Java. It used the inflation value and the Central Java GRDP rate as the response variable, and the BI rate as the predictor variable. BI rate data were taken from the Bank Indonesia web site and Central Java inflation and GDP data were taken from the Central Java BPS web site. The data used were quarterly data for the first quarter of 2007- second quarter of 2019. Quarterly data were recorded in March, quarter II in June, quarter III in September, and quarter IV in December. The GRDP rate data used was the Central Java GRDP rate (yoy) and the inflation data used was also Central Java inflation (yoy) in the same month, namely March, June, September and December. BI rate data used were also data for March, June, September and December. The data analysis procedure was as follows: 1) Conducting a theoretical study of the biresponse regression model with the spline truncated and linear methods with estimated parameters using the Weighted Least Square (WLS) method; 2) Data was dividing into 2 parts, namely data in sample and data out sample; 3) Spline modeling on in-sample data by determining the number of knots 1,2,3,4,5 and combination of orders 2,3,4 in responses 1 and 2, and linear modeling; 4) Calculating the MSE value of the spline model for each knot point and combining the order taken and MSE on the linear model; 5) Choosing the minimum MSE value to determine the best model; 6) Calculating the value of $\mathrm{R}^{2}$ for both models; 7) Evaluating model performance by calculating MAPE outs of samples; 8) Making a conclusion.

\section{RESULTS AND DISCUSSION}

If we are given data pairs of $\left(\mathrm{X}_{\mathrm{i}}, \mathrm{Y}^{(\mathrm{k})}{ }_{\mathrm{i}}\right), \mathrm{k}=1,2, \mathrm{i}=1,2, \ldots, n$, according to the following model of biresponse regression :

$$
Y_{i}^{(k)}=g^{(k)}\left(X_{i}\right)+\varepsilon_{i}^{(k)}, \mathrm{k}=1,2 \text { and } \mathrm{a}<\mathrm{X}_{\mathrm{i}}<\mathrm{b}
$$

where $k$ where $\mathrm{k}$ demonstrates the response number, and $g^{(k)}$ is an unknown regression function and $\varepsilon_{i}^{(k)}$ is an independent random error with zero mean and variant $\sigma_{i}^{2(k)}$ (Lestari et al., 2012). The purpose of biresponse regression modeling is to find estimates of the unknown function $\mathrm{g}^{(\mathrm{k})}$. There are 2 approaches in estimating the function $\mathrm{g}^{(\mathrm{k})}$, namely parametric and nonparametric methods. Parametric methods includes linear models and nonparametric methods covers kernel, spline, local polynomial models, etc.

\subsection{Nonparametric Model of Biresponse Spline Truncated}

Biresponse regression is a regression analysis that involves two correlated response variables. If biresponse regression has an unknown form of regression curve, the approach used is nonparamteric, one of which is biresponse spline truncated regression. The model for nonparametric biresponse spline truncated regression with one predictor variable can be written as follows: 


$$
\begin{aligned}
& \boldsymbol{y}^{(\mathbf{1})}{ }_{i}=\beta_{0}^{(1)}+\sum_{s=1}^{m_{1}-1} \beta_{s}^{(1)} x_{i}^{s}+\sum_{j=1}^{r} \beta_{\left(j+m_{1}-1\right)}^{(1)}\left(x_{i}-K_{j}^{(1)}\right)_{+}^{m_{1}-1}+\varepsilon^{(1)}{ }_{i} \\
& \boldsymbol{y}^{(2)}{ }_{i}=\beta_{0}^{(2)}+\sum_{s=1}^{m_{2}-1} \beta_{s}^{(2)} x_{i}^{s}+\sum_{j=1}^{r} \beta_{\left(j+m_{2}-1\right)}^{(2)}\left(x_{i}-K_{j}^{(2)}\right)_{+}^{m_{2}-1}+\varepsilon^{(2)}{ }_{i}
\end{aligned}
$$

Where $i=1,2,3, \ldots, n$

$$
\begin{aligned}
& m_{1}: \text { order for response } 1 \\
& m_{2}: \text { order for response } 2 \\
& r: \text { Number of knots used for predictor variables }
\end{aligned}
$$

The biresponse spline truncated regression model with one predictor variable can be presented in the following matrix:

$$
\boldsymbol{Y}=\boldsymbol{X} \boldsymbol{\beta}+\boldsymbol{\varepsilon}
$$

where

$$
\begin{aligned}
& \mathbf{Y}=\left[\begin{array}{c}
\boldsymbol{y}^{(\mathbf{1})} \\
-- \\
\boldsymbol{y}^{(\mathbf{2})}
\end{array}\right]_{(\mathbf{2 n} \boldsymbol{x} \mathbf{1})} ; \boldsymbol{y}^{(\mathbf{1})}=\left[\begin{array}{c}
y_{1}^{(1)} \\
y_{2}^{(1)} \\
\vdots \\
y_{n}^{(1)}
\end{array}\right] \text { and } \boldsymbol{y}^{(\mathbf{2})}=\left[\begin{array}{c}
y_{1}^{(2)} \\
y_{2}^{(2)} \\
\vdots \\
y_{n}^{(2)}
\end{array}\right] \\
& \mathbf{X}=\left[\begin{array}{c|c}
A & B \\
- & - \\
C & D
\end{array}\right]_{\left(2 n \times\left(m_{1}+m_{2}+2 r\right)\right)}
\end{aligned}
$$

where

$$
\begin{aligned}
& A=\left[\begin{array}{cccccccc}
1 & x_{1} & x_{1}^{2} & \ldots & x_{1}^{m_{1}-1} & \left(x_{1}-K_{1}^{(1)}\right)_{+}^{m_{1}-1} & \ldots & \left(x_{1}-K_{r}^{(1)}\right)_{+}^{m_{1}-1} \\
1 & x_{2} & x_{2}^{2} & \ldots & x_{2}^{m_{1}-1} & \left(x_{2}-K_{1}^{(1)}\right)_{+}^{m_{1}-1} & \ldots & \left(x_{2}-K_{r}^{(1)}\right)_{+}^{m_{1}-1} \\
\vdots & \vdots & \vdots & & \vdots & & & \vdots \\
1 & x_{n} & x_{2}^{2} & \cdots & x_{n}^{m_{1}-1} & \left(x_{n}-K_{1}^{(1)}\right)_{+}^{m_{1}-1} & \cdots & \left(x_{n}-K_{r}^{(1)}\right)_{+}^{m_{1}-1}
\end{array}\right]_{\left(n x\left(m_{1}+r\right)\right)} \\
& D=\left[\begin{array}{cccccccc}
1 & x_{1} & x_{1}^{2} & \ldots & x_{1}^{m_{2}-1} & \left(x_{1}-K_{1}^{(2)}\right)_{+}^{m_{2}-1} & \ldots & \left(x_{1}-K_{r}^{(2)}\right)_{+}^{2-1} \\
1 & x_{2} & x_{2}^{2} & \ldots & x_{2}^{m_{2}-1} & \left(x_{2}-K_{1}^{(2)}\right)_{+}^{m_{2}-1} & \ldots & \left(x_{2}-K_{r}^{(2)}\right)_{+}^{m_{2}-1} \\
\vdots & \vdots & \vdots & & \vdots & & & \vdots \\
1 & x_{n} & x_{2}^{2} & \cdots & x_{n}^{m_{2}-1} & \left(x_{n}-K_{1}^{(2)}\right)_{+}^{m_{2}-1} & \cdots & \left(x_{n}-K_{r}^{(2)}\right)_{+}^{m_{2}-1}
\end{array}\right]_{\left(n x\left(m_{2}+r\right)\right)} \\
& \mathbf{B}=[\mathbf{0}]_{\left(n x\left(m_{2}+r\right)\right)} ; \mathbf{C}=[\mathbf{0}]_{\left(n x\left(m_{1}+r\right)\right)} \\
& \boldsymbol{\beta}=\left[\begin{array}{c}
\boldsymbol{\beta}^{(\mathbf{1})} \\
-- \\
\boldsymbol{\beta}^{(2)}
\end{array}\right]_{\left(2 \boldsymbol{r}+\boldsymbol{m}_{\mathbf{1}}+\boldsymbol{m}_{2}\right)} \text { where } \boldsymbol{\beta}^{(\mathbf{1})}=\left[\begin{array}{c}
\beta_{0}^{(1)} \\
\beta_{1}^{(1)} \\
\vdots \\
\beta_{\left(\mathrm{r}+\mathrm{m}_{1}-1\right)}^{(1)}
\end{array}\right] ; \boldsymbol{\beta}^{(\mathbf{2})}=\left[\begin{array}{c}
\beta_{0}^{(2)} \\
\beta_{1}^{(2)} \\
\vdots \\
\beta_{\left(\mathrm{r}+\mathrm{m}_{2}-1\right)}^{(1)}
\end{array}\right]
\end{aligned}
$$




$$
\boldsymbol{\varepsilon}=\left[\begin{array}{c}
\boldsymbol{\varepsilon}^{(\mathbf{1})} \\
-- \\
\boldsymbol{\varepsilon}^{(\mathbf{2})}
\end{array}\right]_{(\mathbf{2 n} \boldsymbol{x} \mathbf{1})} \text { where } \boldsymbol{\varepsilon}^{(\mathbf{1})}=\left[\begin{array}{c}
\varepsilon_{1}^{(1)} \\
\varepsilon_{2}^{(1)} \\
\vdots \\
\varepsilon_{n}^{(1)}
\end{array}\right] \text { dan } \boldsymbol{\varepsilon}^{(\mathbf{1})}=\left[\begin{array}{c}
\varepsilon_{1}^{(2)} \\
\varepsilon_{2}^{(2)} \\
\vdots \\
\varepsilon_{n}^{(2)}
\end{array}\right]
$$

There are several scenarios about the order and knot points in responses 1 and 2 . The orders in responses 1 and 2 can be the same or different from the value of the knot point. However, this study is limited only to the value of the knot points in response 1 and 2 to be the same while the idea is not limited to be the same. Estimation of the parameter $\boldsymbol{\beta}$ in equation (3) was done using the Weighted Least Square (WLS) method by minimizing the Weighted Error Squared Sum that is $\boldsymbol{\varepsilon}^{\boldsymbol{T}} \boldsymbol{W} \boldsymbol{\varepsilon}=(\boldsymbol{Y}-\boldsymbol{X} \boldsymbol{\beta})^{\boldsymbol{T}} \boldsymbol{W}(\boldsymbol{Y}-\boldsymbol{X} \boldsymbol{\beta})$ then $\widehat{\boldsymbol{\beta}}$ is an estimator of the least squared weighted for $\boldsymbol{\beta}$ with $\widehat{\boldsymbol{\beta}}=\left(\boldsymbol{X}^{\boldsymbol{T}} \boldsymbol{W} \boldsymbol{X}\right)^{-\mathbf{1}} \boldsymbol{X}^{\boldsymbol{T}} \boldsymbol{W} \boldsymbol{Y}$. In the case of regression modeling with more than one response as in the nonparametric biresponse regression analysis, we need a $\mathrm{W}$ weighting matrix involving correlation and covariance values. According to $\mathrm{Wu}$ and Zhang (2006), weighting matrices involving correlation and covariance values are $\boldsymbol{W}=\boldsymbol{V}^{-1}$; where $\boldsymbol{V}=$ the covariance variance matrix of the response variable.

It is possible to determine the best performance of the regression function by several criteria, including those that have the smallest GCV, CV or MSE values (Suparti et al, 2018b). Nevertheless, the optimization model in this study is based on the smallest MSE value, namely MSE $=\frac{(\mathrm{Y}-\widehat{\mathrm{Y}})^{\mathrm{T}}((\mathrm{Y}-\widehat{\mathrm{Y}}))}{\mathrm{N}}, \mathrm{I}=\mathrm{NxN}$ identity matrix, $\mathrm{N}=2 \mathrm{n}$.

\subsection{Modeling Inflation Data and GRDP Rate with the BI Rate.}

For example the response variable $\mathrm{Y}_{1}$ : inflation, $\mathrm{Y}_{2}$ : GRDP rate and predictor variable $\mathrm{X}_{1}$ : $\mathrm{BI}$ rate. Data were divided into 2 parts, namely data in sample and out sample. In sample data consisted of 44 observations namely 2007 quarter I data - IV quarter 2017 while out sample data consisted of 6 observations, namely quarter I data 2018 - II quarter 2019. In sample data was used to build the model and out sample data was used to evaluate the performance of the model by measuring the performance of the model based on MAPE values. MAPE could be calculated using the following formula:

$$
M A P E=\frac{1}{N} \sum_{k=1}^{2} \sum_{i=1}^{n}\left|\frac{Y_{(k) i}-\widehat{Y}_{(k) i}}{Y_{(k) i}}\right| \times 100 \%
$$

Where $Y_{(k) i}:$ the actual value of the data in the $\mathrm{i}$-th observation for the $\mathrm{k}$-th response

$\hat{Y}_{(k) i}:$ the predicted value of $\mathrm{Y}$ at the $\mathrm{i}$-th observation for the $\mathrm{k}$-th response

$n \quad:$ number of observations per response

$N: 2 \mathrm{n}$

The smaller the obtained MAPE value the better the performance of the model. According to Halimi et al. (2013), the evaluation values should have the following MAPE criteria:

1. MAPE $<10 \%$ : very good forecasting ability

2. $10 \% \leq \mathrm{MAPE}<20 \%$ : good forecasting ability

3. $20 \% \leq \mathrm{MAPE}<50 \%$ : sufficient forecasting ability

4. MAPE $\geq 50 \% \quad$ : poor forecasting ability 
Data modeling was done by taking a combination of order in response 1 and 2 that is 2, 3, and 4; while the number of knots points that were tried for $1,2,3,4$, and 5 was a combination of points on the BI rate data from the second data up to the 43 data by taking the BI rate observation data which are all different. Table 1 shows the optimal model results at each knot point 1-5.

Table 1. Summary of Optimal Model at each Knot Point

\begin{tabular}{ccclcc}
\hline \multirow{2}{*}{$\begin{array}{c}\text { Number of } \\
\text { Knot Point }\end{array}$} & \multicolumn{2}{c}{ Optimal Order } & & \multicolumn{1}{c}{ Knot Point } & $\begin{array}{c}\text { Minimal } \\
\text { MSE }\end{array}$ \\
\cline { 2 - 3 } & $\mathbf{m}_{\mathbf{1}}$ & $\mathbf{m}_{\mathbf{2}}$ & & & 1.194 \\
2 & 4 & 4 & 9 & 1.112 \\
3 & 4 & 4 & $(8.5 ; 9)$ & 1.062 \\
4 & 4 & 4 & $(5.75 ; 6 ; 9)$ & 1.042 \\
5 & 4 & 4 & $(5.75 ; 6 ; 6.5 ; 9)$ & 1.007 \\
\hline
\end{tabular}

In sample data modeling was conducted by minimizing the MSE value. The optimal model has the same order of 4 and the number of knots for the BI rate variable is 5 , which is at point $(4.75 ; 7.5 ; 7.75 ; 8 ; 8.25)$. The optimal model has a value of MSE $=1.007$ with $\mathrm{R}^{2}$ of $65.30428 \%$. Scatter plot data and models are presented in Figures 1 and 2.

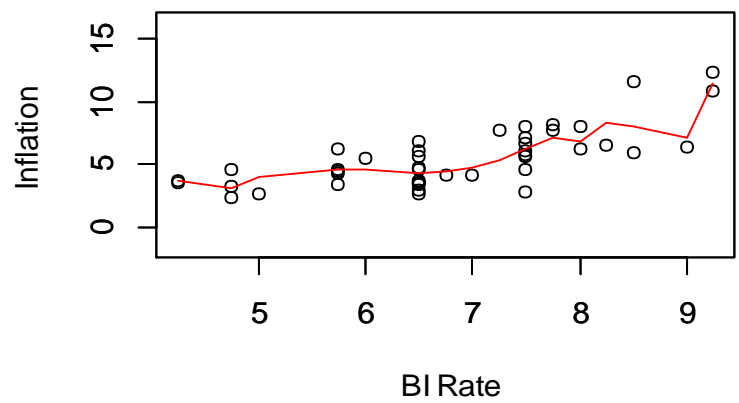

Figure 1. Inflation Model with spline truncated ooooooooooooooo : actual data

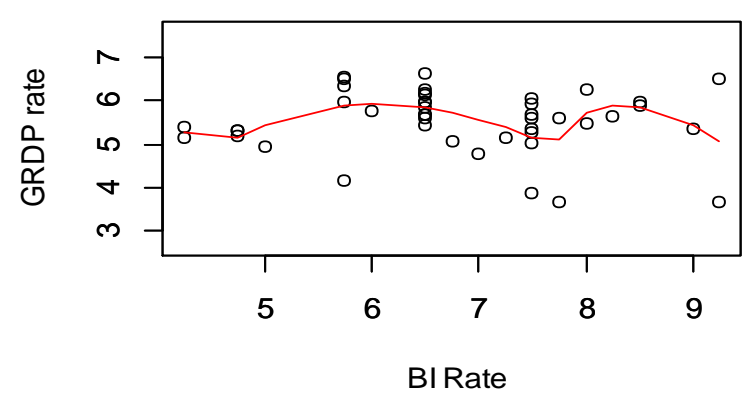

Figure 2. GRDP Rate Model with Spline Truncated : spline truncated model

The MAPE out sample was calculated from the obtained optimal model at $38.66151 \%$, which shows that the quote good performance of the model because the value of $20 \% \leq \mathrm{MAPE}<50 \%$.

\subsection{Biresponse Liner Regression}

Scatter plot between inflation data and GRDP rate with BI rate (Figures 1 and 2) shows almost a straight line pattern, which can be regressed using biresponse linear regression. Therefore, the authors are interested in comparing between the spline model and the biresponse linear model on inflation data and the Central Java GRDP rate.

The linear response model of (1) is

$$
Y_{i}^{(k)}=\theta_{0}^{(k)}+\theta_{1}^{(k)}\left(X_{i}\right)+\varepsilon_{i}^{(k)}, k=1,2 ; \mathrm{i}=1,2, \ldots, n
$$


If the data on the response to $k$-th, $\mathbf{Y}^{(\mathbf{k})}=\left(\begin{array}{c}\mathrm{Y}_{1}^{(k)} \\ \mathrm{Y}_{2}^{(k)} \\ \vdots \\ \mathrm{Y}_{n}^{(k)}\end{array}\right)$ and the data on the predictor variable, $\mathbf{X}=\left(\begin{array}{c}X_{1} \\ X_{2} \\ \vdots \\ X_{n}\end{array}\right)$ the biresponse linear regression model (4) can be written in matrix form to

$$
\mathbf{Y}=\boldsymbol{X}_{\mathbf{1}}{ }^{*} \boldsymbol{\theta}+\boldsymbol{\varepsilon}
$$

where : $\mathbf{Y}=\left[\begin{array}{l}\mathbf{Y}^{(\mathbf{1})} \\ \mathbf{Y}^{(\mathbf{2})}\end{array}\right]_{(2 n x 1)}$ with $\mathbf{Y}^{(\mathbf{1})}=\left[\begin{array}{c}\mathrm{Y}_{1}^{(1)} \\ \mathrm{Y}_{2}^{(1)} \\ \vdots \\ \mathrm{Y}_{n}^{(1)}\end{array}\right], \mathbf{Y}^{(\mathbf{2})}=\left[\begin{array}{c}\mathrm{Y}_{1}^{(2)} \\ \mathrm{Y}_{2}^{(2)} \\ \vdots \\ \mathrm{Y}_{n}^{(2)}\end{array}\right]$

$$
\boldsymbol{X}_{\mathbf{1}}{ }^{*}=\operatorname{diag}\left(\mathbf{X}^{*}, \mathbf{X}^{*}\right)=\left[\begin{array}{cc}
\mathbf{X}^{*} & \mathbf{0} \\
\mathbf{0} & \mathbf{X}^{*}
\end{array}\right]_{(2 n x 4)}, \text { with } \mathbf{X}^{*}=\left[\begin{array}{cc}
1 & X_{1} \\
1 & X_{2} \\
\vdots & \vdots \\
1 & X_{n}
\end{array}\right]_{(n x 2)}, \mathbf{0}=\left[\begin{array}{cc}
0 & 0 \\
0 & 0 \\
\vdots & \vdots \\
0 & 0
\end{array}\right]_{(n x 2)}
$$

$$
\boldsymbol{\theta}=\left[\begin{array}{l}
\boldsymbol{\theta}^{(\mathbf{1})} \\
\boldsymbol{\theta}^{(2)}
\end{array}\right]=\left[\begin{array}{c}
\theta_{0}^{(1)} \\
\theta_{1}^{(1)} \\
\theta_{0}^{(2)} \\
\theta_{1}^{(2)}
\end{array}\right]_{(\mathbf{4 x \mathbf { 1 }})}
$$

and $\quad \boldsymbol{\varepsilon}=\left[\begin{array}{l}\boldsymbol{\varepsilon}^{(\mathbf{1})} \\ \boldsymbol{\varepsilon}^{(2)}\end{array}\right]_{(2 n x 1)}$ with $\boldsymbol{\varepsilon}^{(\mathbf{1})}=\left[\begin{array}{c}\varepsilon_{1}^{(1)} \\ \varepsilon_{2}^{(1)} \\ \vdots \\ \varepsilon_{\mathrm{n}}^{(1)}\end{array}\right]_{(n \times \mathbf{1})}, \boldsymbol{\varepsilon}^{(2)}=\left[\begin{array}{c}\varepsilon_{1}^{(2)} \\ \varepsilon_{2}^{(2)} \\ \vdots \\ \varepsilon_{\mathrm{n}}^{(2)}\end{array}\right]_{(\boldsymbol{n} x \mathbf{1})}$

Linear model estimator (6) can be solved using Weighted Least Square (WLS) by minimizing the sum of the weighted error squared, namely $\varepsilon^{T} W \varepsilon=\left(Y-X_{1}^{*} \theta\right){ }^{T} W(Y-$ $\left.\boldsymbol{X}_{\mathbf{1}}^{*} \boldsymbol{\theta}\right)$ led to $\widehat{\boldsymbol{\theta}}=\left(\mathbf{X}_{\mathbf{1}}{ }^{* \mathrm{~T}} \boldsymbol{W} \mathbf{X}_{\mathbf{1}}{ }^{*}\right)^{-\mathbf{1}} \mathbf{X}_{\mathbf{1}}{ }^{* \mathbf{T}} \mathbf{W Y}$. The computing using software R resulted in an optimal linear model with the value of $\mathrm{MSE}=1.519$ and $\mathrm{R}^{2}=47.65273 \%$. The formed linear model is presented in Figures 3 and 4. The MAPE out sample value is calculated from the obtained linear model with $35.42724 \%$ which shows that the model has a quite good performance because the value is of $20 \% \leq$ MAPE $<50 \%$.

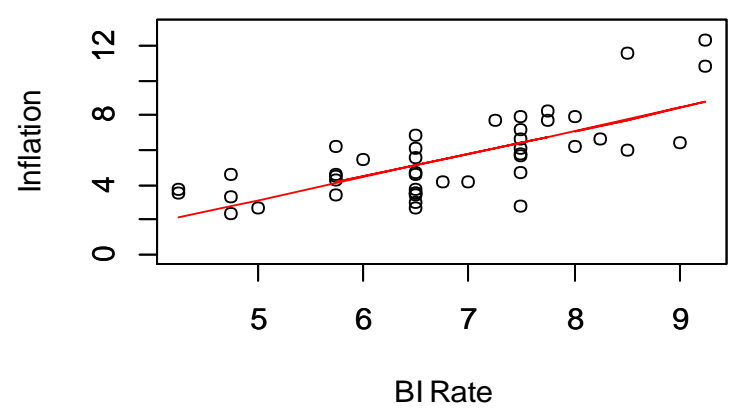

Figure 3. Inflation Linear Model

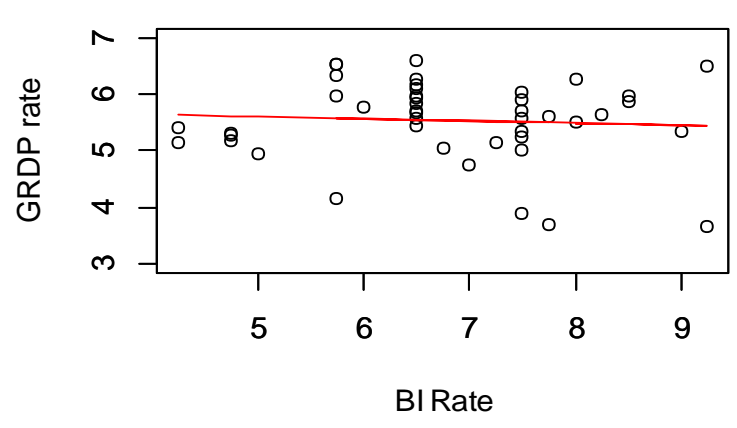

Figure 4. GRDP Rate Linear Model 


\subsection{Comparison of Spline Truncated and Biresponse Linear Models in Central Java's Inflation Data and GRDP Rate}

The results of spline truncated modeling and linear models in this case include the MSE, $\mathrm{R}^{2}$ and MAPE out sample values are presented in Table 2.

Table 2. Comparison Between Spline Truncated and Biresponse Linear Model

\begin{tabular}{lcc}
\hline \multicolumn{1}{c}{ Model } & Spline Truncated Biresponse Model & Biresponse Linear Model \\
\hline MSE & 1.007 & 1.519 \\
$\mathrm{R}^{2}$ & $65.30428 \%$ & $47.65273 \%$ \\
Out Sample MAPE & $38.66151 \%$ & $35.42724 \%$ \\
Performance & Sufficient & Sufficient \\
\hline
\end{tabular}

Of the two models, the spline truncated model has a smaller MSE value and $\mathrm{R}^{2}$ that is greater than the biresponse linear model. This indicates that the spline truncated model is better than the linear model. This can also be seen visually in Figures 1, 2, 3 and 4. Figures 1 and 2 highlights that the estimated spline truncated model is closer to the actual data than Figures 3 and 4. Although the MAPE out sample value in the linear model is smaller than the spline model truncated, both models show quite good performance.

\section{CONCLUSION}

The best model with the same order was resulted from the use of quarterly data in 2007 - 2019, and by taking into account the BI rate variable, namely order 4 with 5 number of knots. The spline truncated model is better than the linear biresponse model, as seen from the MSE and $\mathrm{R}^{2}$ values. However, the drawbacks of this study are the same location of the knots in response 1 and response 2 . It would be better to try various possible locations of the knot points in responses 1 and 2 in different places because the changing pattern in the function of inflation data and the GDP rate show different locations of BI rate. It is suggested to support this result by more sophisticated computer devices because it will require a very large memory.

\section{ACKNOWLEDGEMENT}

The authors would like to express gratitude to the Directorate of Research and Community Service, Ministry of Research, Technology and Higher Education (DRPM Kemenristek Dikti) for funding this research through the Higher Education Applied Research (PTUPT) scheme for the 2019 budget year.

\section{REFERENCES}

Agusmianata, N., Militina, T., and Lestari, D. 2017. Pengaruh Jumlah Uang Beredar dan Tingkat Suku Bunga serta Pengeluaran Pemerintah terhadap Inflasi di Indonesia. Forum Ekonomi, Vol. 19, No. 2, pp. 188-200. 
Ampulembang, A. P., Otok, B. W., and Rumiati, A. T. 2016. Modeling of Welfare Indicators in Java Island Using Biresponses MARS. International Journal of Applied Mathematics and Statistics, Vol. 54, No. 2, pp. 66-75.

Chamidah, N. and Rifada, M. 2016. Estimation of Median Growth Curves for Children Up Two Years Old Based On Biresponse Local Linear Estimator. AIP Conference Proceedings 1718, pp. 342-347

Fahrika, A. I. 2016. Pengaruh Tingkat Suku Bunga melalui Investasi Swasta terhadap Pertumbuhan. Economics, Social and Development Sudies, Vol 3, No. 2, pp. 43-70.

Fernandes, A. A. R., Budiantara, I. N., Otok, B. W., and Suhartono. 2014. Spline Estimator for Bi-responses Nonparametric Regression Model for Longitudinal Data. Applied Mathematical Sciences, Vol. 8, No. 114, pp. 5653-5665.

Halimi, R., Anggraeni, W., and Tyasnurita, R. 2013. Pembuatan Aplikasi Peramalan Jumlah Permintaan Produk dengan Metode Time Series Exponential Smoothing Holts Winter di PT.Telekomunikasi Indonesia Tbk. Jurnal Teknik POMITS Vol. 1 No. 1, pp. 1-6.

Indriyani, S. 2016. Analisis Pengaruh Inflasi dan Suku Bunga Terhadap Pertumbuhan Ekonomi Di Indonesia Tahun 2005-2015. Jurnal Manajemen Bisnis Krisnadwipayana, Vol 4, No 2.

Lestari, B., Chamidah, N., and Saifudin, T. 2019. Estimasi Fungsi Regresi Dalam Model Regresi Nonparametrik Birespon Menggunakan Estimator Smoothing Spline dan Estimator Kernel. Jurnal Matematika, Statistika dan Komputasi, Vol. 15, No. 2, pp. $20-25$.

Nurdiani, N., Heryanto, N., and Darari, D. 2018. Regresi Nonparametrik Birespon Spline. Jurnal Eureka Matika, Vol.5, pp. 106-121

Panjaitan, M. N. Y. and Wardoyo. 2016. Faktor-Faktor yang Mempengaruhi Inflasi di Indonesia. Jurnal Ekonomi Bisnis, Vol.21, No. 3, pp. 182-193

Pratiwi, L. P. S. 2017. Pemodelan Spline Truncated dalam Regresi Nonparametrik Birespon. E-Proceedings KNSI STIKOM Bali, pp. 441-445

Suparti. 2013. Analisis Data Inflasi di Indonesia Menggunakan Model Regresi Spline. Media Statistika, Vol. 6, No. 1, pp. 1-9.

Suparti, Prahutama, A., and Santoso, R. 2018a. Mix Local Polynomial And Spline Truncated: The Development of Nonparametric Regression Model. Journal of Physics: Conference series, Vol. 1025, Issue 1, pp. 1-7.

Suparti, Prahutama, A., Santoso, R., and Devi, A. R. 2018b. Regresi Nonparametrik. Ponorogo: Wade Group.

Suparti, Prahutama, A., Rahmawati, R., and Utami, T. W. 2016. Modelling Local Polynomial for Longitudinal Data A Case Study; Inflation Sectors in Indonesia. ARPN Journal of Engineering and Aplied Science (JEAS), Vol. 11, No. 23, pp. 13974-13979

Wu, H. and Zhang, J.T. 2006. Nonparametric Regression Methods for Longitudinal Data Analysis. New Jersey: A John-Wiley and Sons Inc. Publication. 
Wulandari, I. D. A. M. I. and Budiantara. I. N. 2014. Analisis Faktor-Faktor yang Mempengaruhi Persentase Penduduk Miskin dan Pengeluaran Perkapita Makanan di Jawa Timur Menggunakan Regresi Nonparametrik Birespon Spline. Jurnal Sains dan Seni ITS, Vol. 3, No. 1, pp. 30-35. 